Available online at http://www.anpad.org.br/bar

BAR, Curitiba, v. 8 , n. 1, art. 4, pp. 48-67, Jan./Mar. 2011

\title{
Relationship between Abnormal Earnings Persistence, Industry Structure, and Market Share in Brazilian Public Firms
}

\author{
Antonio Carlos Coelho * \\ E-mail address: acarloscoelho@terra.com.br \\ Universidade Federal do Ceará \\ Fortaleza, CE, Brazil. \\ Andson Braga de Aguiar \\ E-mail address: abraga@usp.br \\ Universidade de São Paulo \\ São Paulo, SP, Brazil. \\ Alexsandro Broedel Lopes \\ E-mail address: broedel@usp.br
} Universidade de São Paulo and Comissão de Valores Mobiliários ${ }^{(1)}$

São Paulo, SP, Brazil.

* Corresponding author: Antonio Carlos Coelho

Av. da Universidade, 2431, Fortaleza, CE, 60020-180, Brazil.

Copyright (C) 2011 Brazilian Administration Review. All rights reserved, including rights for translation. Parts of this work may be quoted without prior knowledge on the condition that the source is identified. 


\begin{abstract}
In this study, Ohlson's Linear Information Dynamic (LID) is analyzed and the effect of other information on the abnormal earnings series is evaluated. The hypothesis that industry structure and market share have significant effects on abnormal earnings in the following period is tested, with Ohlson's LID persistence maintained. The results confirm the premise of LID in a sample of Brazilian public firms, considering all the statistical models. The hypothesis regarding market share is rejected as its effect on the degree of abnormal earnings persistence has no informational content, either directly or jointly. Finally, the results confirm that different industries affect abnormal earnings persistence differently. In view of these results, the research hypotheses are partially rejected. It is concluded that (a) industry contains other information that can impact abnormal earnings for the following period and (b) market share (in isolation and together with industry concentration) does not imply differentiated impacts on firms' abnormal earnings for the following period, and therefore do not reflect the presence of other information in Ohlson's Model (1995).
\end{abstract}

Key words: abnormal earnings persistence; Ohlson's Model; industry structure; market share; emerging markets. 


\section{Introduction}

The valuation model proposed by Ohlson (1995) suggests that firm value can be estimated through abnormal earnings and other information. One of the premises on which this model is based is Linear Information Dynamics, which establishes relationships of persistence in the time series of accounting profits.

Acceptance of the premise of LID enables the prediction of abnormal earnings for the following period from abnormal earnings of the current period and other information, which in turn records any relevant information, not yet reflected in accounting figures, used in the prediction of abnormal future earnings, which, however, has already been recorded in the firm market value (Ohlson, 1995).

In other words, other information summarizes relevant events that will have an impact on future financial statements, which means that other information will impact future abnormal earnings, without depending on past abnormal earnings (Lopes, 2001a).

Despite its importance for predicting future abnormal earnings, other information has been systematically neglected in studies that use the Ohlson's Model (1995, as cited in Hand, 2001). Two likely implications of this are, on the one hand, the reduction of empirical content of the model (Ohlson, 2001) and, on the other, the acceptance of the assumption that only publicly available accounting information influences the firm's valuation (Hand, 2001).

In the present study, this gap is addressed and industry economy variables as other information are formally included in Ohlson's Model (1995). Specifically, the following research questions are addressed: Do industry and market share firm size of Brazilian firms have informational content in Ohlson's Model (1995)? Do they have any effects on future abnormal earnings in a sample of Brazilian firms?

It is thus expected that industry data, such as industry and market share, will affect future abnormal earnings (Owens, 2001). Hence they can be seen as a source of other information whose inclusion in Ohlson's Model will likely increase its empirical content.

It has been argued that the industry structure has a strong influence on the determination of the competitive rules of the game, as well as the strategies potentially available to the company (Porter, 2004).

Regarding the effect of industry structure on earnings, Porter (2004) argues that the competition in an industry acts continually in reducing the rate of return on invested capital towards the basic competitive rate of return. Thus, different industries will cause different effects on abnormal earnings persistence according to their structure.

Accordingly, as industry structure does not have an immediate effect on firms' performance (Kupfer, 1992), it is argued that such an effect will only be reflected in accounting data with some time delay. Thus, industry structure will only affect future abnormal earnings, but it will be already registered in the market price of firms that make up that industry.

Assuming, on the one hand, Porter's (2004) argument that industry affects the rate of return and, on the other, that the effect of the industry structure will only be reflected in the accounting data of firms that comprise that industry with some time delay, the hypothesis is tested that different industries have different temporal relationship with the abnormal earnings of the following period, with Ohlson's (1995) LID persistence maintained.

It is expected, therefore, that the firm's abnormal earnings persistence will depend on the structure of the industry of which it forms a part, so that different industries will cause different effects on abnormal earnings persistence. More precisely, it is expected that current industry structure will affect the abnormal earnings of the firms that comprise that industry in the following period. 
Moreover, it is supposed that the effect of industry structure on abnormal earnings persistence will be different from the effect of the level of firms' competitiveness on this persistence (Cheng, 2005). The degree of a firm's competitiveness, measured by its market share in the industry in which it operates, derives from its competitive strategies adopted according to its expectations regarding those that appear most efficient, but only with some time delay will market performance sanction whether the choices were right or wrong (Kupfer, 1992, p. 4).

As the firm's competitiveness will only be reflected in its future performance, it is also argued that market share firm size represents other information that will affect future abnormal earnings.

Therefore, the hypothesis that market share has a statistically significant temporal relationship with abnormal earnings of the following period is tested, with Ohlson's (1995) LID persistence maintained. It is expected that firms that currently have a greater market share will show higher abnormal earnings in the following period.

Furthermore, the combined effect of industry structure and market share on future abnormal earnings is also tested. Kupfer (1992) mentions that industry structure can cover a wide range of company sizes and as a result it is supposed that firms in an industry do not share the excess profits in that industry equally. Moreover, Porter (2004) mentions that different industries affect future abnormal earnings differently. Accordingly, it is argued that firms with the same market share but performing in different industries, as well as firms at the same industry but with different market shares, will affect future abnormal earnings in different ways.

The hypothesis that industry structure and market share jointly have a statistically significant temporal relationship with abnormal earnings of the following period, with Ohlson's (1995) LID persistence maintained, is then tested. Thus, it is expected that both industry structure and market share simultaneously affect future abnormal earnings.

Abnormal earnings are calculated using Ohlson's (1995) valuation model, with a risk-free interest rate as the cost of capital being applied. What should then follow is what Ohlson (1995) originally proposed in his model. Moreover, it is assumed that the risk premium, included in models such as the CAPM (Capital Asset Pricing Management), will already be represented in other information.

Industry is determined by the Economática database (tool designed for investment analysis with data from firms installed in American countries) classification. Market share firm size is calculated by taking its net revenue as a percentage of the total revenue of the industry of which it forms a part, which is in turn weighted by its relative size. A one-period time delay in the analysis of the hypotheses is considered, which is consistent with Ohlson's Model and allows the testing of the first-order autoregressive process - AR (1) - which is predicted in the abnormal earnings series.

Three control variables are included: industry concentration index, GDP growth and firm size. The sample is comprised of all Brazilian firms listed on BOVESPA (the Brazilian stock market) whose financial information is available on Economática database for the calculation of abnormal earnings in all periods between 1996 and 2005. The regression technique with panel data is employed.

The remainder of this article is structured as follows: in the following section, the theoretical background is discussed, along with the hypotheses on which it is based; in the third part, the methodological procedures for selection, collection, processing and analysis of data are described; in the fourth part, the results are analyzed; in the fifth part, the conclusions are discussed. 


\section{Theoretical Background and Hypotheses}

\section{Ohlson's valuation model}

Various studies have analyzed the relevance of accounting information for firm valuation, focusing on the identification of which accounting figures best explain the firm market value. Some of these studies are based on fundamentalist analysis for firm valuation (Kothari, 2001), which determines the firm value through an examination of the value drivers, such as profit, risk, growth and competitive positioning (Lev \& Thiagarajan, 1993).

Ohlson's (1995) valuation model by abnormal earnings is one of the most prominent analytical studies in empirical accounting research that attempts to explain the firm value in a fundamentalist way.

In comparison to other approaches to fundamental analysis, Ohlson's (1995) valuation model uses accounting data as the most important value driver instead of the present value of discounted future dividends or discounted future cash flows (Owens, 2001). As a result, Ohlson's model does not require assumptions to be made concerning the relationship between earnings and dividends or cash flows by emphasizing how future accounting data links directly to firm value (Owens, 2001). premises:

The validity of the abnormal earnings model proposed by Ohlson (1995) is based on three

. The present value of expected dividends determines the intrinsic firm value;

. Profit satisfies the relationship of Clean Surplus Relation and dividends reduce the accounting value of shareholders' equity without affecting current profits;

. A persistent link exists between contemporary accounting figures and future abnormal earnings Linear Information Dynamic (LID).

Ohlson (1995) defines the firm value $\left(\mathrm{P}_{\mathrm{t}}\right)$ as being the sum of the contemporary value of

shareholders' equity $\left(\mathrm{y}_{\mathrm{t}}\right)$ and the present value of expected future residual profits $\left({ }_{t+\tau}^{a}\right)$; in other words, the firm value is equal to its contemporary accounting valuation adjusted by the present value of future abnormal earnings (1).

$$
P_{t}=y_{t}+\sum_{\tau=1}^{\infty} R f^{-\tau} E_{t}\left[x_{t+\tau}^{a}\right]
$$

Therefore, the development of Ohlson's Model emphasizes the role of abnormal earnings as a variable that influences firm value.

Abnormal earnings are estimated by the difference between the firm's total profits $\left(\mathrm{x}_{\mathrm{t}}\right)$ and a charge for the use of capital, which in turn is measured by the risk-free rate of interest (r), applied to the shareholders' equity at the beginning of the period $\left(y_{t-1}\right)(2)$.

$$
x_{t}^{a}=x_{t}-r\left(y_{t-1}\right)
$$

Ohlson's Model (1995) is therefore built on the foundations provided by Residual Income Valuation (RIV) model that is not empirically testable (Lo \& Lys, 2000). Thus, the main contribution of Ohlson's Model (1995) is to provide additional assumptions linking the RIV model to testable propositions by modeling the information dynamics (Lo \& Lys, 2000).

Given the premise of the Linear Information Dynamic (LID), the model assumes that abnormal earnings follow a stochastic time series process, first-order autoregressive - AR (1). In general, linear 
information models enable the development of valuation models based on empirically testable accounting data and suggest a link between contemporary accounting figures and future abnormal earnings (Myers, 1999).

The premise of LID is thus essential to the validity of Ohlson's (1995) valuation model seeing that it permits firm value to be estimated by means of contemporary and future accounting figures. The acceptance of the premise of LID enables the prediction of abnormal earnings of the following period from both abnormal earnings of the current period and other information not yet reflected in accounting data.

Therefore, Ohlson predicts in his model that other information, beyond accounting data, influences abnormal earnings persistence, even though accounting data remains as the principal element in the proposed valuation model.

Thus, abnormal earnings follow a linear time series sequence in which abnormal earnings on date $(t+1)$ depends upon abnormal earnings on date $(t)$ plus other information $\left(v_{t}\right)$ on date $(t)$ as well (3).

$$
x_{t+1}^{a}=\omega x_{t}^{a}+v_{t}+\varepsilon_{1 t+1}
$$

Other information can be any non-accounting information contained in the prediction of future abnormal earnings (Ohlson, 1995), such as industry data (e.g. industry structure and competitiveness) and macroeconomic data (e.g. GDP growth) (Owens, 2001). The variable other information also satisfies a first-order autoregressive process (4).

$$
v_{\mathrm{t}+1}=\gamma v_{\mathrm{t}}+\varepsilon_{2 \mathrm{t}+1}
$$

Ohlson (1995) asserts that the error terms, $\varepsilon_{1 \tau}$, $\varepsilon_{2 \tau}$, being $\tau \geq 1$, are unpredictable variables, with an average of zero. Moreover, the parameters of persistence, $\omega$ and $\gamma$, are fixed and known, with the restriction of not being negative and less than 1, which makes possible the prediction of abnormal earnings of the following period from abnormal earnings of the current period and from other information, given its stationary condition. In any other way a random walk behavior of abnormal earnings would be experienced, making the prediction difficult.

This aspect is fundamental for the proposed valuation model, that is, the non-acceptance of the premise of LID would make difficult the prediction of abnormal earnings as well as the estimation of the firm value.

Therefore, other information $\left(\mathrm{v}_{\mathrm{t}}\right)$ summarizes relevant value events that will cause an impact on future financial statements. It will thus cause an impact on abnormal earnings of the following period, without depending on past and contemporary abnormal earnings, which are already recorded in the shareholders' equity variable. The model also implies that the presence of $\mathrm{v}_{\mathrm{t}}$ (or $\varepsilon_{2 \tau}$ ) cannot be avoided in financial statements, i.e., even with one-period time delay, other information will be contained in future financial statements.

Moreover, greater values of the parameters of persistence increase long-term abnormal earnings persistence, that is, the closer to 1 the parameter of abnormal earnings persistence $(\omega)$, the more those abnormal earnings will be reflected in subsequent periods.

Lo and Lys (2000) mention that the parameters $\omega$ and $\gamma$ are sufficient to differentiate processes in which profits are purely transitory from processes in which profits are highly persistent. Cupertino and Lustosa (2004) mention that the criteria for obtaining the parameters $\omega$ or $\gamma$ were not established, it being supposed that economic environment and accounting principles determine the exogenous parameters $\omega$ and $\gamma$ (Ohlson, 1995). 
Moreover, it is likely that this information will immediately be priced by the market, especially when it is associated with bad news. It is then expected that the risk attributed by the market to the firm will only be reflected by the accounting information in the abnormal earnings of the following period (Basu, 1997).

Various studies have empirically tested the firm valuation model through abnormal earnings proposed by Ohlson (1995): Choi, O'Hanlon and Pope (2006), Dechow, Hutton and Sloan (1999), Galdi and Lopes (2006), Lopes (2001b), Lopes and Teixeira (2003), Monahan (2005), Sant'anna, Louzada and Costa (2005), Walker and Wang (2003). However, studies using Ohlson's (1995) model have not paid attention to the informational content of other information. Moreover, the few studies that included that variable in the explanation of abnormal earnings did so in an intuitive manner, rather than formally (Hand, 2001).

It is worth mentioning some studies that have modified Ohlson's Model (1995). For instance, Myers (1999) uses CAPM as the cost of capital instead of the risk-free interest rate. However, considering the accounting conservatism that does not allow the recognition of the risk-premium associated to an investment, the effect of the cost of capital will be reflected by other information.

Ohlson (2001) argues that not including other information in the firm valuation model, even when analytically interesting, reduces the empirical content of the model. Hand (2001) adds that establishing a null value for other information is equal to assuming that only publicly available accounting data influences the firm valuation.

Ohlson (2001) asserts that the main reason that other information is not considered in empirical tests of his model derives from the fact that it is not easily specified.

Therefore, this study investigates the premise of the Linear Information Dynamic of Ohlson's (1995) valuation model to estimate abnormal earnings, including industry structure and market share as other information. It is thus argued that industry structure and market share will be reflected in accounting data in the following period, increasing the informational and empirical content of the valuation model.

\section{Industry structure and market share}

Porter (2004) asserts that industry is the principal aspect of the firms' environment and that industry structure exerts a strong influence on determining the competitive rules of the game, as well as the strategies potentially available to the company.

Porter (2004) argues, furthermore, that industry competition affects the rate of return on invested capital, reducing it continually towards the basic competitive rate of return or the return that would be obtained in an industry with perfect competition.

In other words, competition in an industry makes its abnormal earnings decrease towards zero, which means that its degree of abnormal earnings persistence will be lower than in industries where competition is not perfect. The reasoning is that the presence of rates of return higher than the basic competitive rate of return stimulates the entry of new capital into an industry, this entry being caused by new firms or by firms already established in the industry (Porter, 2004).

Porter (2004) adds that the combination of competitive forces in an industry determines to which point this influx of investment occurs and guides the return towards the level of free market rates, and thus, the capacity of companies to keep returns above average.

Porter (2004) suggests that the industry structure is affected by the following five basic competitive forces, reflecting that competition is not limited to firms already established in the industry: potential entrants, buyers, suppliers, substitutes and competitors in the industry. Porter 
(2004) considers that these basic competitive forces determine the industry's potential final profit, which is measured in terms of long-term return on invested capital.

It is argued that not all industries possess the same potential for profit, taking into account that they differ to the extent that the basic competitive forces differ (Porter, 2004). Hence, different industry structures are unlikely to affect abnormal earnings persistence.

This study acknowledges Porter's (2004) expectations and argues that different industry structures have different effects on abnormal earnings series.

Moreover, industry structure does not immediately affect firms' performance (Kupfer, 1992). Being an ex-post phenomenon, industry structure will only affect firms' future performance. If so, it is expected that the effect of industry will solely be reflected in accounting data with some time delay, but it will already be registered by the shares market price of companies that comprise that industry.

In view of Porter's (2004) arguments that different industries cause different effects on the rate of return obtained in that industry, and Kupfer's (1992), for whom the effect of industry structure will only be reflected in accounting data with some time delay, the first hypothesis of this study is formulated as follows:

H1: Different current industry structure has a different statistically significant temporal relationship with abnormal earnings of firms that comprise that industry in the following period, Ohlson's (1995) LID persistence also having the first-order autoregressive process maintained.

It is thus expected that there will be different relationships between abnormal earnings persistence of firms in an industry and its industry structure, so that different industries will result in different abnormal earnings persistence.

Furthermore, Porter argues that external forces acting upon an industry, affecting all the firms in that industry, should be understood in a relative sense or in the sense of how each firm deals with these forces. If so, Porter (2004) judges that the objective of a firm's competitive strategy in an industry is to find a position within it in which the company can best defend itself against these competitive forces and influence them in its favor.

Therefore, it is supposed that different firms have different reactions to external forces acting upon a certain industry, so that they do not have the same level of participation or market share in the industry's current abnormal earnings. It is therefore supposed that the effect of industry structure on abnormal earnings persistence will be different from the effect of market share firm size on that persistence (Cheng, 2005).

Market share firm size derives from firms' expectations regarding those competitive strategies that appear most efficient and will only affect firm performance some time in the future (Kupfer, 1992).

In view of Cheng's (2005) and Kupfer's (1992) arguments, the second hypothesis of this study is formulated as follows:

H2: Current market share firm size has a positive and statistically significant temporal relationship with the firms' abnormal earnings of the following period, Ohlson's (1995) LID persistence as well as first-order autoregressive process being maintained.

A positive relationship is thus expected between firm abnormal earnings persistence and market share firm size, so that firms with greater current market share will have greater abnormal earnings persistence, with positive results.

Finally, Kupfer (1992) asserts that industry structure can cover various distributions of firm sizes. It is thus argued that, on the one hand, firms in an industry do not share the excess profits in that 
industry equally and, on the other, different industries affect future abnormal earnings differently (Porter, 2004).

Accordingly, it is expected that firms with the same market share but performing in different industries, as well as firms at the same industry but with different market shares, will affect future abnormal earnings in different ways.

This study, therefore, tests the combined effect of industry structure and market share on future abnormal earnings. The third hypothesis of this study is formulated as follows:

H3: Industry structure and market share jointly have a positive and statistically significant temporal relationship with the firms' abnormal earnings of the following period, Ohlson's (1995) LID persistence as well as first-order autoregressive process being maintained.

Thus, it is expected that both industry structure and market share simultaneously affect future abnormal earnings so that it is not sufficient for a firm to have a great market share to guarantee future abnormal earnings, it may also perform in an industry whose structure sustains future abnormal earnings.

\section{Methodology}

\section{Sample selection}

Financial data from Brazilian public companies were collected in 2006 from the Economática database. There were a total of 577 firms, but only 135 firms exhibited useful data for all years between 1995 and 2005. The year 1995 was included in order to allow the abnormal earnings estimation for 1996. Thus, abnormal earnings were calculated for all the 135 sample firms from 1996 to 2005 .

For each firm, the following financial information was gathered: (a) shareholders' equity, (b) net profit; (c) net revenue and (d) total assets. The first two pieces of information were used to estimate abnormal earnings in accordance with equation (2). Net revenue was used to determine market share. Finally, total assets were used to eliminate scale effect.

\section{Variable measurement}

Abnormal earnings were calculated in accordance with equation (2), in which they are estimated by the difference between accounting profit and a charge for the use of capital, which is in turn measured by the risk-free interest rate multiplied by the accounting value of shareholders' equity at the beginning of the period. As the risk-free interest rate, the Brazilian annual return on savings was adopted, according to information contained in the Portal Brasil ${ }^{\circledR}$ database.

The risk-free interest rate is used according to what is originally predicted by Ohlson (1995). In addition, even though it would be possible use the market interest rate (e.g. CAPM), it is assumed that the risk premium predicted by CAPM will be reflected by either abnormal earnings, in the case of an anticipation of future losses, or other information, in the case of not being registered by accounting. It is also worth mentioning previous empirical studies that have applied CAPM as the cost of capital in order to estimate abnormal earnings (Myers, 1999) and have been not successful in delivering significantly different results from those obtained when the a risk-free interest rate is applied (T-Bill Yield) (Cheng, 2005).

Industry structure, reflecting other information, was determined by Economática classification. The sample comprised the following 17 industries (Table 1). 
Table 1

Industries - Economática

\begin{tabular}{llll}
\hline Agriculture \& Fishing & Electrical Energy & Non-metallic Minerals & Steel Production \& Metallurgy \\
Food \& Beverages & Finance \& Insurance & Others & Software \& Data \\
Commerce & Funds & Paper e Cellulose & Telecommunications \\
Construction & Industrial Machinery & Petroleum \& Gas & Textiles \\
Electronics & Mining & Chemicals & Transport \& Services \\
& & & Automotive \\
\hline
\end{tabular}

The industries Finance and Insurance, Funds, and Software and Data were excluded as they did not exhibit complete data between 1995 and 2005. In addition, the industry Others was excluded due to the heterogeneity of the firms that it comprises. All the useful industries were represented by dummy variables $\left(D_{s}\right)$.

Market share firm size $\left(\mathrm{MS}_{\mathrm{it}}\right)$ was measured as the ratio between its annual sales and its annual industry sales. In order to allow comparability between the market share of firms operating in different industries, market share firm size was weighted by a quotient calculated between its industry size and the average size of all industries.

The calculation of that quotient involved two steps:

Average size of all industries - calculated by the sum of the net revenue of all firms included in the sample, divided by the number of industries (17 industries);

. Quotient - calculated by the quotient between industry size (the sum of net revenue of all firms that comprise a certain industry) and average industry size. That value was hence employed as a weighting factor.

It is important to consider that, even though the industry economy literature does not determine the time delay in which the industrial structure will affect future abnormal earnings (Kupfer, 1992), a one-period time delay is adopted in order to be consistent with what was originally predicted by Ohlson (1995), whose prediction is that other information will affect abnormal earnings in the following period.

Three control variables were included: industry concentration index $\left(\mathrm{IHH}_{\mathrm{t}}\right)$, annual GDP growth $\left(\mathrm{GDP}_{\mathrm{t}}\right)$, and firm size $\left(\right.$ Sales $\left._{\mathrm{t}+1}\right)$.

The Hirschman-Herfindahl index (IHH) was employed to calculate the industry concentration index. IHH is calculated by the sum of squared market share $\left(\mathrm{S}_{\mathrm{i}}\right)$ of all firms in an industry - IHH = $\sum_{i}\left(S_{i}\right)^{2}$ (Besanko, Dranove, \& Shanley, 2000). GDP growth data were gathered from an official Brazilian public agency. Firm size was measured by the net revenue as collected from the Economática database.

\section{Regression models}

The following statistical models were tested:

Initially, there was an evaluation of whether the parameter of persistence $(\omega)$ was statistically significant and whether its value was between zero and 1 (5);

$$
x_{t+1}^{a}=\alpha+\varpi x_{t}^{a}+\varepsilon_{t+1}
$$


- The second step was the processing of model (5) controlled by firm size in order to examine its relevance to other information $(5 \mathrm{a})$;

$$
x_{t+1}^{a}=\alpha+\omega x_{t}^{a}+\delta_{3} \text { Sales }_{t+1}+\varepsilon_{t+1}
$$

Next, the three control variables were included in order to remove their potential effect on the parameter of persistence $(5 \mathrm{~b})$;

$$
x_{t+1}^{a}=\alpha+\omega x_{t}^{a}+\delta_{1} I H H_{t}+\delta_{2} \Delta G D P_{t}+\delta_{3} \text { Sales }_{t+1}+\varepsilon_{t+1}
$$

. In model (5), industry dummies were included to evaluate whether industry concentration had informational content, that is, if the industry concentration coefficient $(\beta)$ was positive and statistically significant (6);

$$
x_{t+1}^{a}=\alpha+\varpi x_{t}^{a}+\sum_{s=1}^{17} \beta_{s} D_{s}+\varepsilon_{t+1}
$$

. Model (6) was then processed including firm size as control variable (6a);

$$
x_{t+1}^{a}=\alpha+\varpi_{t}^{a}+\sum_{s=1}^{17} \beta_{s} D_{s}+\delta_{3} \text { Sales }_{t+1}+\varepsilon_{t+1}
$$

Furthermore, model (6) was also processed including the three control variables (6b);

$$
x_{t+1}^{a}=\alpha+\omega x_{t}^{a}+\sum_{s=1}^{17} \beta_{s} D_{s}+\delta_{1} I H H_{t}+\delta_{2} \Delta G D P_{t}+\delta_{3} \text { Sales }_{t+1}+\varepsilon_{t+1}
$$

- In model (5), market share was included to evaluate whether this variable offers informational content, that is, if the market share coefficient $(\theta)$ was positive and statistically significant (7);

$$
x_{t+1}^{a}=\alpha+\varpi x_{t}^{a}+\theta M S_{t}+\varepsilon_{t+1}
$$

. Model (7) was then processed including just firm size as control variable (7a);

$$
x_{t+1}^{a}=\alpha+\omega x_{t}^{a}+\theta M S_{t}+\delta_{3} \text { Sales }_{t+1}+\varepsilon_{t+1}
$$

. Furthermore, model (7) was processed including the three control variables (7b);

$$
x_{t+1}^{a}=\alpha+\omega x_{t}^{a}+\theta M S_{t}+\delta_{1} I H H_{t}+\delta_{2} \Delta G D P_{t}+\delta_{3} \text { Sales }_{t+1}+\varepsilon_{t+1}
$$

. Using model (5), the combined effect of industry structure and market share was also tested (8);

$$
x_{t+1}^{a}=\alpha+\varpi x_{t}^{a}+\sum_{s=1}^{17} \beta_{s} D_{s}+\theta M S_{t}+\varepsilon_{t+1}
$$

. Model (8) was thus processed including firm size as control variable (8a);

$$
x_{t+1}^{a}=\alpha+\varpi x_{t}^{a}+\sum_{s=1}^{17} \beta_{s} D_{s}+\theta M S_{t}+\delta_{3} \text { Sales }_{t+1}+\varepsilon_{t+1}
$$

. Finally, the three control variables (8b) were added to model (8).

$$
x_{t+1}^{a}=\alpha+\varpi x_{t}^{a}+\sum_{s=1}^{17} \beta_{s} D_{s}+\theta M S_{t}+\delta_{1} I H H_{t}+\delta_{2} \Delta G D P_{t}+\delta_{3} \text { Sales }_{t+1}+\varepsilon_{t+1}
$$


For each model dummies were added, as control variables, representing the years. The variables $M S$ (market share), IHH (industrial concentration index) and $\triangle G D P$ (GDP growth rate) are displayed in percentages. The other variables represent absolute values in Brazilian currency ( $\$$ ). To reduce the scale effect of these variables in relation to those represented in percentages, they were divided by total assets at the beginning of the period.

\section{Data analysis}

In order to estimate the model parameters, panel data analysis was employed using the STATA statistics package. Panel data analysis is appropriate when the sample size consists of different firms with longitudinal data (Gujarati, 2006). Several methods that combine all the data in cross-section and in time series were tested to estimate the models. Therefore, ordinary least squares, (OLS), fixed effects (FE), random effects (RE), first differences (FD) and Arellano-Bond's (GMM) dynamic model were applied (Wooldridge, 2002) in order to identify the most consistent and efficient econometric relationship for the final analysis.

Therefore, sequential tests were carried out, using both static and dynamic panel data methods in order to appoint a satisfactory econometric structural model. Arellano-Bond's showed the most consistent and efficient estimation, given the condition of time lag of one period between dependent and independent variables. Thus, the analysis was carried out using this method.

However, we present the parameter estimation by all these methods, providing additional econometric information, conducting data analysis through GMM method columns.

The tests shown in Table 2 were performed in order to select the appropriate regression method for data processing. These tests take into account the identification of consistent and efficient parameters.

The econometric tests detected the presence of heteroscedasticity, which weakens the efficiency of the estimators. Therefore, robust variance matrixes were used in all models. Moreover, omitted variables were detected, which implies inconsistency in OLS estimators. Accordingly, panel data processing tests that foresee non-observable components were applied.

Sequential tests were processed using static panel techniques - Fixed Effects and Random Effects - (F - Fixed Effects, Breusch-Pagan, and Hausman) aiming to identify efficient and consistent econometric parameters. Nevertheless, they showed contradictory results, leading to a decision in favor of dynamic panel methods.

Table 2

Econometric Tests

\begin{tabular}{ll}
\hline \multicolumn{1}{c}{ Tests } & \multicolumn{1}{c}{ Evaluation Carried Out } \\
\hline Breusch-Pagan/Cook Weisberg & $\begin{array}{l}\text { Evaluates the presence of Heteroscedasticity in residuals distribution by } \\
\text { ordinary least squares (OLS) } \\
\text { Tests the existence of Omitted Variables in the Model under } \\
\text { consideration } \\
\text { Ramsey reset }\end{array}$ \\
Examines whether the Error Variance is equal to zero. If such a \\
Bypothesis is rejected, it chooses the results generated by the method of \\
Random Effects in contraposition to OLS \\
Examines the Hypothesis of coefficients significance generated by the \\
F Test - Fixed Effects
\end{tabular}


Table 2 (continued)

\begin{tabular}{|c|c|}
\hline Tests & Evaluation Carried Out \\
\hline Hausman & $\begin{array}{l}\text { Allows for choosing the most consistent and efficient method between } \\
\text { Random Effects and Fixed Effects }\end{array}$ \\
\hline Autocorrelation of residuals & $\begin{array}{l}\text { Tests the presence of autocorrelation by the regression between } \\
\text { estimated residuals (used in the case of regressions with lagged variables) }\end{array}$ \\
\hline Sargan Test & $\begin{array}{l}\text { Tests of correlation between instrumental variables and estimated errors; } \\
\text { examines whether it exists under Instrument identification }\end{array}$ \\
\hline
\end{tabular}

The first difference regression models indicate serial autocorrelation. Therefore, the final test was conducted using instrumental variables, in accordance with the Arellano-Bond method. This deals with a technique using Generalized Method of Moments (GMM) that assumes correction for the generic identification of the model. It is stressed that the instruments were adequate, according to the indications of the Sargan test, which identifies the model by correlation analysis between instrumental variables and estimated error. Thus, coefficients estimated by GMM - dynamic panel - present the most adequate results for the purposes of this research.

\section{Result Analysis}

\section{Abnormal earnings persistence}

The first step corresponds to significance analysis of the parameters of persistence, not including other information. In Table 3, the parameters of persistence of Ohlson's (1995) premise are listed, as well as their statistical significance and explanatory power, estimated according to the three proposed models $(5,5 \mathrm{a}$, and $5 \mathrm{~b})$, with dummies added registering the non-observable effects related to the periods under consideration.

Table 3

Coefficients of Persistence

\begin{tabular}{|c|c|c|c|c|c|c|c|}
\hline & \multirow[b]{2}{*}{ MODELS } & \multicolumn{6}{|c|}{ METHODS } \\
\hline & & OLS & $\begin{array}{c}\text { Random } \\
\text { Effects }\end{array}$ & $\begin{array}{l}\text { Fixed } \\
\text { Effects }\end{array}$ & $\begin{array}{c}\text { First } \\
\text { Differences }\end{array}$ & 2SLS & $\begin{array}{c}\text { GMM } \\
\text { (Arellano-Bond) }\end{array}$ \\
\hline \multirow{3}{*}{5} & Coefficient $\omega$ & 0.44 & 0.44 & 0.20 & -0.38 & 0.19 & 0.21 \\
\hline & Test $z / t$ & 5.95 & 5.95 & 2.27 & -4.57 & 11.15 & 2.08 \\
\hline & $\mathrm{R}^{2} / \mathrm{Wald}$ & $24 \%$ & 434.49 & $20 \%$ & $15 \%$ & 548.28 & 88.43 \\
\hline \multirow[t]{3}{*}{$5 a$} & Coefficient $\omega$ & 0.43 & 0.43 & 0.19 & -0.37 & 0.19 & 0.21 \\
\hline & Test $\mathrm{z} / \mathrm{t}$ & 5.78 & 5.78 & 2.22 & -4.36 & 11.38 & 2.14 \\
\hline & $\mathrm{R}^{2} /$ Wald & $24 \%$ & 475.31 & $14 \%$ & $15 \%$ & 608.79 & 96.16 \\
\hline \multirow[t]{3}{*}{$5 b$} & Coefficient $\omega$ & 0.43 & 0.43 & 0.19 & -0.37 & 0.19 & 0.21 \\
\hline & Test $z / t$ & 5.75 & 5.75 & 2.22 & -4.35 & 10.97 & 2.18 \\
\hline & $\mathrm{R}^{2} /$ Wald & $25 \%$ & 474.24 & $14 \%$ & $15 \%$ & 621.71 & 97.49 \\
\hline
\end{tabular}


It can be seen from the three models that the estimated parameters have similar results, all of them statistically significant. Thus, it can be interpreted that variations in previous abnormal earnings cause positive, i.e., persistent, variations (around 21\%) in subsequent abnormal earnings.

The control variables added to model 5 (firm size, industrial concentration index and GDP variations) do not appear to affect abnormal earnings persistence, meaning that it is not possible to attribute interference of sales volumes (5a) as well as all control variables (5b) to the abnormal earnings series.

\section{Abnormal earnings persistence and industry structure}

The first research hypothesis predicts that different current industry structure has a different statistically significant temporal relationship with abnormal earnings of firms that comprise that industry in the following period, Ohlson's (1995) LID persistence as well as first-order autoregressive process being maintained.

Table 4 shows the significance analysis of the parameters of persistence, their statistical significance and their statistical power, including the effect of industry structure as other information. Dummies were added to the proposed models $(6,6 \mathrm{a}$, and $6 \mathrm{~b})$ in order to identify nonobservable effects pertaining to the periods under consideration.

The parameters of persistence estimated for these three models remain statistically significant, with previous abnormal earnings explaining around 22\% (GMM) of the variations in subsequent abnormal earnings.

Table 4

Coefficients of Persistence and Industry Concentration

\begin{tabular}{|c|c|c|c|c|c|c|c|}
\hline & \multirow[b]{2}{*}{ MODELS } & \multicolumn{6}{|c|}{ METHODS } \\
\hline & & OLS & $\underset{\text { Effects }}{\text { Random }}$ & Fixed Effects & $\begin{array}{c}\text { First } \\
\text { Differences }\end{array}$ & 2SLS & $\begin{array}{c}\text { GMM } \\
\text { (Arellano-Bond) }\end{array}$ \\
\hline & Coefficient $\omega$ & 0.40 & 0.40 & 0.20 & -0.38 & 0.20 & 0.23 \\
\hline \multirow[t]{2}{*}{6} & Test $t / z$ & 5.31 & 5.31 & 2.27 & -4.57 & 12.12 & 2.32 \\
\hline & $\mathrm{R}^{2} / \mathrm{Wald}$ & $26 \%$ & 582.49 & $20 \%$ & $15 \%$ & $4,896.84$ & 324.90 \\
\hline \multirow[t]{3}{*}{$6 a$} & Coefficient $\omega$ & 0.40 & 0.40 & 0.19 & -0.38 & 0.19 & 0.22 \\
\hline & Test $\mathrm{t} / \mathrm{z}$ & 5.26 & 5.26 & 2.22 & -4.35 & 11.10 & 2.35 \\
\hline & $\mathrm{R}^{2} /$ Wald & $27 \%$ & 619.24 & $14 \%$ & $16 \%$ & $5,238.93$ & 279,83 \\
\hline \multirow[t]{3}{*}{$6 \mathrm{~b}$} & Coefficient $\omega$ & 0.40 & 0.40 & 0.19 & -0.38 & 0.19 & 0.22 \\
\hline & Test $\mathrm{t} / \mathrm{z}$ & 5.25 & 5.25 & 2.22 & -4.35 & 11.01 & 2.35 \\
\hline & $\mathrm{R}^{2} / \mathrm{Wald}$ & $27 \%$ & 625.92 & $14 \%$ & $16 \%$ & $5,469.03$ & 274.18 \\
\hline
\end{tabular}

The hypothesis that industry structure affects future abnormal earnings is not rejected (at usual levels of statistical significance). Table 5 shows the differential coefficients of each industry with their respective tests of significance.

It can be seen that most industries do not affect abnormal earnings of the following period. Moreover, it is stressed that without control variables (model 6), the industries Mining, Paper and Cellulose, Chemicals, and Steel Production and Metallurgy positively and significantly affect abnormal earnings in the following period. 
Table 5

Differential Coefficients - Industry (Processed by GMM/Arellano-Bond)

\begin{tabular}{lcccccc}
\hline \multirow{2}{*}{\multicolumn{1}{c}{ INDUSTRIES }} & \multicolumn{7}{c}{ MODELS } \\
\cline { 2 - 7 } & \multicolumn{2}{c}{$\mathbf{6}$} & \multicolumn{2}{c}{$\mathbf{6 a}$} & $\mathbf{6 b}$ \\
\cline { 2 - 7 } & Coefficient $\boldsymbol{\beta}$ & Test $\mathbf{z}$ & Coefficient $\boldsymbol{\beta}$ & Test z & Coefficient $\boldsymbol{\beta}$ & Test $\mathbf{z}$ \\
\hline Agriculture \& Fishing & -0.04 & -1.41 & 0.01 & 0.93 & 0.01 & 0.53 \\
Food \& Beverages & 0.00 & 0.24 & -0.01 & -0.66 & -0.03 & -1.21 \\
Commerce & 0.00 & 0.32 & -0.02 & -1.20 & -0.03 & -1.53 \\
Construction & 0.01 & 1.24 & 0.01 & 0.86 & -0.02 & -0.70 \\
Electronics & 0.01 & 1.49 & 0.00 & 0.20 & -0.01 & -0.78 \\
Electrical Energy & 0.01 & 1.53 & 0.01 & 1.48 & -0.01 & -0.55 \\
Industrial Machinery & 0.00 & 0.71 & -0.00 & -0.13 & -0.01 & -0.80 \\
Mining & 0.03 & $2.24^{* *}$ & 0.03 & $1.76^{* * *}$ & 0.04 & $2.56^{*}$ \\
Non-Metallic Minerals & -0.00 & -0.37 & -0.01 & -0.91 & -0.03 & -1.33 \\
Paper \& Cellulose & 0.02 & $1.97^{* *}$ & 0.01 & $1.69^{* * *}$ & -0.00 & -0.26 \\
Petroleum \& Gas & 0.01 & 1.06 & -0.02 & -0.98 & -0.03 & -1.12 \\
Chemicals & 0.02 & $1.79^{* * *}$ & 0.01 & 0.63 & -0.02 & -0.69 \\
Steel Production \& Metallurgy & 0.03 & $2.36^{* *}$ & 0.02 & $1.63^{* * *}$ & -0.00 & -0.25 \\
Telecommunications & 0.01 & 1.46 & 0.01 & 0.99 & -0.01 & -0.69 \\
Textiles & 0.00 & 0.55 & -0.00 & -0.29 & -0.03 & -1.14 \\
Transport \& Services & -0.03 & $-3.26^{*}$ & -0.06 & $-3.55^{*}$ & -0.07 & $-3.50^{*}$ \\
Automotive & 0.01 & 1.18 & 0.00 & 0.14 & -0.01 & -0.70 \\
\hline & & & & & &
\end{tabular}

Note. Significant to $* 1 \% ; * * 5 \%$ e $* * * 10 \%$

This positive and significant effect persists for the Mining industry after the inclusion of all control variables (Models 6a and 6b). However, the effect of the industries Paper and Cellulose and Steel Production and Metallurgy on future abnormal earnings remains positive and significant only when firm size is included as control variable (6a), but not for all control variables (6b).

Finally, the most interesting result refers to the effect of the Transport and Services industry on abnormal earnings persistence as it has a negative and significant correlation with future abnormal earnings.

Given these results, the research hypothesis that different industries have a different statistically significant temporal relationship with abnormal earnings of the following period, with LID persistence as well as first-order autoregressive process maintained, is accepted for Brazilian industries. Most of the industries do not exhibit informational content as other information, since the coefficients $(\beta)$ are not statistically different from zero, whereas some industries exhibit informational content as other information, positively or negatively affecting future abnormal earnings.

\section{Abnormal earnings persistence and market share}

The second research hypothesis predicts that current market share firm size has a positive and statistically significant temporal relationship with its abnormal earnings of the following period, Ohlson's (1995) LID persistence as well as first-order autoregressive process being maintained. 
In Table 6, the parameters of persistence of Ohlson's (1995) premise are listed, as well as their statistical significance and explanatory power, including the effect of market share as other information. The estimates consider the three proposed models $(7,7 \mathrm{a}$, and $7 \mathrm{~b})$, with dummies added in order to identify non-observable effects.

Table 6

Coefficients of Persistence and Market Share

\begin{tabular}{llccccc}
\hline \multirow{2}{*}{ MODELS } & \multicolumn{5}{c}{ METHODS } \\
\cline { 3 - 7 } & OLS & Random Effects & Fixed Effects & First Differences & GMM (Arellano-Bond) \\
\hline \multirow{3}{*}{7} & Coefficient $\omega$ & 0.43 & 0.43 & 0.20 & -0.38 & 0.22 \\
& Test $\mathrm{t}$ & 5.81 & 5.81 & 2.25 & -4.57 & 2.13 \\
& $\mathrm{R}^{2} /$ Wald & $24 \%$ & 456.36 & $21 \%$ & $15 \%$ & 89.89 \\
& Coefficient $\omega$ & 0.42 & 0.42 & 0.19 & -0.38 & 0.22 \\
$7 \mathrm{a}$ & Test t & 5.66 & 5.66 & 2.21 & -4.36 & 2.19 \\
& $\mathrm{R}^{2} /$ Wald & $25 \%$ & 496.39 & $14 \%$ & $15 \%$ & 98.27 \\
& Coefficient $\omega$ & 0.42 & 0.42 & 0.19 & -0.37 & 0.22 \\
$7 \mathrm{~b}$ & Test t & 5.65 & 5.65 & 2.21 & -4.35 & 2.22 \\
& $\mathrm{R}^{2} /$ Wald & $25 \%$ & 497.19 & $14 \%$ & $15 \%$ & 98.64 \\
\hline
\end{tabular}

It can be seen once again that the parameters of persistence estimated by the three models are statistically significant, with explanatory power of approximately $22 \%$.

The hypothesis that market share firm size affects abnormal earnings of the following period is rejected (at the usual levels of statistical significance). Table 7 shows the market share coefficients $(\theta)$ of each model $(7,7 \mathrm{a}$, and $7 \mathrm{~b})$ with their respective tests of significance. It is shown that not only does market share have no effect on the coefficients of abnormal earnings persistence, but also that it relates negatively to future earnings, contrary to the predictions of extant industry literature.

Table 7

Coefficients $\beta$ - Market Share (Processed by GMM/Arellano-Bond)

\begin{tabular}{ccccc}
\hline MODELS & Coefficient $\boldsymbol{\omega}$ & Test $\mathbf{z}$ & Coefficient $\boldsymbol{\theta}$ & Test $\mathbf{z}$ \\
\hline 7 & 0.22 & 2.13 & -0.025 & -0.71 \\
$7 \mathrm{a}$ & 0.22 & 2.19 & -0.039 & -0.84 \\
$7 \mathrm{~b}$ & 0.22 & 2.22 & -0.023 & -0.56 \\
\hline
\end{tabular}

Given these results, the research hypothesis that market share has a statistically significant temporal relationship with the abnormal earnings of the following period, Ohlson's (1995) LID persistence as well as first-order autoregressive process being maintained, is not accepted for Brazilian firms. The inclusion of market share firm size does not offer informational content, since its coefficients $(\theta)$ are not statistically different from zero. 


\section{Abnormal earnings persistence, industry structure, and market share}

The third research hypothesis predicts that industry structure and market share firm size jointly possess a positive and statistically significant temporal relationship with firms' abnormal earnings for the following period, Ohlson's (1995) LID persistence as well as first-order autoregressive process being maintained.

Table 8 shows that the parameters of persistence estimated by the three models $(8,8 \mathrm{a}$, and $8 \mathrm{~b})$ are positive and statistically significant, with the coefficients oscillating at around $23 \%$ regardless of the effect of both control variables and other information, which is represented by industry structure and market share. The estimates also foresee the effect of dummies added in order to identify nonobservable effects related to the periods under study.

Table 8

Coefficients of Persistence and Market Share

\begin{tabular}{ccccc}
\hline MODELS & Coefficient $\boldsymbol{\omega}$ & Test $\mathbf{z}$ & Coefficient $\boldsymbol{\theta}$ & Test z \\
\hline 8 & 0.23 & 2.34 & -0.02 & -0.65 \\
$8 \mathrm{a}$ & 0.22 & 2.38 & 0.01 & 0.14 \\
$8 \mathrm{~b}$ & 0.22 & 2.39 & 0.01 & 0.20 \\
\hline
\end{tabular}

In Table 8, it can also be seen that market share is not influenced by industry structure in order to jointly affect firms' abnormal earnings of the following period. Such inference derives from the statistical non-significance of the estimated coefficients $(\theta)$, as well as their low value.

In Table 9, the opposite effect is assessed, i.e., if industry structure is affected by market share in order to jointly have an effect on firms' future abnormal earnings.

Table 9

Significant Coefficients of Industry Structure

\begin{tabular}{lcccccc}
\hline \multirow{2}{*}{\multicolumn{1}{c}{ INDUSTRIES }} & \multicolumn{6}{c}{ MODELS } \\
\cline { 2 - 7 } & \multicolumn{2}{c}{$\mathbf{8}$} & \multicolumn{3}{c}{$\mathbf{8 a}$} & \multicolumn{2}{c}{$\mathbf{8 b}$} \\
\cline { 2 - 7 } & Coefficient $\boldsymbol{\beta}$ & Test t & Coefficient $\boldsymbol{\beta}$ & Test t & Coefficient $\boldsymbol{\beta}$ & Test t \\
\hline Mining & 0.03 & $2.22^{* *}$ & 0.03 & $1.69^{* * *}$ & 0.04 & $2.40^{* *}$ \\
Paper \& Cellulose & 0.02 & $1.96^{* *}$ & 0.01 & $1.66^{* * *}$ & & \\
Chemicals & 0.02 & $1.77^{* * *}$ & & & & \\
Steel Production \& Metallurgy & 0.02 & $2.31^{* *}$ & & & & \\
Transport \& Services & -0.03 & $-3.20^{*}$ & -0.06 & $-3.48^{*}$ & -0.07 & $-3.46^{*}$ \\
\hline
\end{tabular}

Note. Significant to $* 1 \% ; * * 5 \%$ and $* * * 10 \%$

The results reinforce those obtained previously (Table 5), showing the same impacts observed in the analysis of the first hypothesis. Hence, the third hypothesis is not accepted, seeing that the combined effect of industry structure and market share causes no further impact on abnormal earnings persistence. 
Finally, it is stressed that the variable firm size is not statistically significant (at a statistical significance level $(\alpha)$ of $10 \%$ ) in any model; which means that the volume of operational activity also has no informational content as other information.

\section{Conclusions}

The premise of Linear Information Dynamic proposed by Ohlson's Model (1995) predicts that future abnormal earnings will be explained by current abnormal earnings and by other information not yet reflected in accounting data. The results of this study confirm this expectation as the abnormal earnings persistence was statistically significant in all models.

The same results hold true for industry structure that shows information that affects abnormal earnings for the following period. However, as predicted, this effect is different for different industries. Accordingly, the results indicate that most of the industries do not exhibit informational content as other information, whereas some industries exhibit informational content as other information, positively or negatively affecting future abnormal earnings.

In the case of market share, the results are not only non-significant, but also reveal negative coefficients. These results are curious, as the extant industry literature predicts that competitiveness (market share) affects firms' future profits. The results indicate that the combined effect of industry structure and market share does not affect the residual income of the following period either. Moreover, firm size does not have a significant impact on the abnormal earnings series, not presenting informational content.

A suggestion for future empirical research is to broaden knowledge concerning the effect of structural industry and market share on abnormal earnings persistence, as the results obtained in this study for Brazilian firms partially contradict the extant theory.

The main implication of this study is that greater market share and greater sales volumes do not guarantee future abnormal earnings, at least in the case of the sample of Brazilian firms included in this study. Furthermore, different industries differently affect future abnormal earnings, suggesting that industry structure contains other information that is likely to affect abnormal future accounting results.

Another avenue for future research is to understand better why some industries positively affect future abnormal earnings while others negatively affect them, as well as why some industries do not affect future abnormal earnings at all. This empirical question can, for example, be explored in terms of the five competitive forces suggested by Porter. In addition, future research can also improve understanding of the factors that affect the distribution of the industry's abnormal earnings among the firms that comprise that industry.

The results obtained in this study might be taken with caution, bearing in mind that accounting figures can be managed, that is, their informational content is not efficient. Moreover, whether accounting figures meet the premise of Clean Surplus Relation is a matter that is open to question.

It is also important to remember that a one-period time delay was applied to investigate the effect of the industry's economy variables on abnormal earnings.; Even though this procedure is consistent with what was originally predicted by Ohlson (1995), that the time delay between the effect of industry variables and abnormal earnings could be more than one period, which could account for the insignificant effect of market share.

Finally, it is stressed the main limitation of this study is that the sample is restricted to public companies listed on the Brazilian share market, which does not necessarily represent the structural industry referred to in the extant literature. Accordingly, the market share measure does not include all 
the firms that comprise a given industry either. The use of a wider sample could lead to different inferences from those presented here. Another limitation of this study is the time period (1995-2005) considered in the analysis. The use of updated data could provide a better understanding of the effects proposed by considering a longer time period.

\title{
Received 02 February 2010; received in revised form 13 July 2010.
}

\author{
Nota \\ ${ }^{1}$ As informações apresentadas neste trabalho não se constituem em posições formais da Comissão de Valores Mobiliários.
}

\section{References}

Basu, S. (1997). The conservatism principle and the asymmetric timeliness of earnings. Journal of Accounting and Economics, 24(1), 3-37.

Besanko, D., Dranove, D., \& Shanley, M. (2000). The economics of strategy (2nd ed.). New York: John Wiley \& Sons.

Cheng, Q. (2005). What determines residual income. The Accounting Review, 80(1), 85-112. doi: 10.2308/accr.2005.80.1.85

Choi, Y., O'Hanlon, J. F., \& Pope, P. F. (2006). Conservative accounting and linear information valuation models. Contemporary Accounting Research, 23(1), 73-101. doi: 10.1506/7Y8HC8PP-8HFR-831W

Cupertino, C. M., \& Lustosa, P. R. B. (2004, October). O modelo Ohlson de avaliação de empresas: tutorial para utilização. Anais do Congresso USP de Controladoria e Contabilidade, São Paulo, SP, Brazil, 4.

Dechow, P. M., Hutton A. P., \& Sloan, R. G. (1999). An empirical assessment of the residual income valuation model. Journal of Accounting and Economics, 26(1-3), 1-34. doi:10.1016/S01654101(98)00049-4

Galdi, F. C., \& Lopes, A. B. (2006, September). Análise empírica de valuation no ambiente brasileiro: fluxo de caixa descontado versus modelo de Ohlson. Anais do Encontro Nacional da Associação Nacional de Pós-Graduação e Pesquisa em Administração, Salvador, BA, Brazil, 30 .

Gujarati, D. N. (2006). Econometria básica (4th ed.). Rio de Janeiro: Elsevier.

Hand, J. R. (2001). Discussion of earnings, book values, and dividends in equity valuation: an empirical perspective. Contemporary Accounting Research, 18(1), 121-130. doi: 10.1506/6A7C-74ML-TGBD-DYBW

Kothari, S. P. (2001). Capital markets research in accounting. Journal of Accounting and Economics, 31(1/3), 105-231. doi: 10.1016/S0165-4101(01)00030-1

Kupfer, D. (1992, December). Padrões de concorrência e competitividade. Anais do Encontro Nacional de Economia da ANPEC, Campos do Jordão, SP, Brazil, 20.

Lev, B., \& Thiagarajan, S. R. (1993). Fundamental information analysis. Journal of Accounting Research, 31(2), 190-215. 
Lo, K., \& Lys, T. (2000). The Ohlson model: contribution to valuation theory, limitations, and empirical applications. Journal of Accounting, Auditing and Finance, 15(3), 337-367.

Lopes, A. B. (2001a). A informação contábil e o mercado de capitais. São Paulo: Pioneira Thomson.

Lopes, A. B. (2001b). A relevância da informação contábil para o mercado de capitais: o modelo de Ohlson aplicado à BOVESPA. Tese de doutorado, Universidade de São Paulo, São Paulo, SP, Brazil.

Lopes, A. B., \& Teixeira, A. J. C. (2003, September). Valuation properties of accounting numbers in Brazil. Anais do Encontro Nacional da Associação Nacional de Pós-Graduação e Pesquisa em Administração, Atibaia, SP, Brazil, 27.

Monahan, S. J. (2005). Conservatism, growth and the role of accounting numbers in the fundamental analysis process. Review of Accounting Studies, 10(2-3), 227-260. doi: 10.1007/s11142-005$1530-8$

Myers, J. N. (1999). Implementing residual income valuation with linear information dynamics. The Accounting Review, 74(1), 1-28. doi: 10.2308/accr.1999.74.1.1

Ohlson, J. A. (1995). Earnings, book values, and dividends in equity valuation. Contemporary Accounting Research, 11(2), 661-687. doi: 10.1111/j.1911-3846.1995.tb00461.x

Ohlson, J. A. (2001). Earnings, book values, and dividends in equity valuation: an empirical perspective. Contemporary Accounting Research, 18(1), 107-120. doi: 10.1506/7TPJ-RXQNTQC7-FFAE

Owens, L. A. (2001). An examination of the relationships between strategy, environment, and performance in a fundamental analysis model. Doctoral dissertation, Oklahoma State University, Stillwater, OK, United States of America.

Porter, M. E. (2004). Estratégia competitiva: técnicas para análise de indústrias e da concorrência. Rio de Janeiro: Campus.

Sant'Anna, D. P., Louzada, L. C., \& Costa, F. M. (2005, September). A relevância das informações contábeis na Bovespa a partir do arcabouço teórico de Ohlson: avaliação dos modelos de Residual Income Valuation e Abnormal Earnings Growth. Anais do Encontro Nacional da Associação Nacional de Pós-Graduação e Pesquisa em Administração, Brasília, DF, Brazil, 29.

Walker, M., \& Wang, P. (2003). Towards an understanding of profitability analysis within the residual income valuation framework. Accounting and Business Research, 33(3), 235-246.

Wooldridge, J. M. (2002). Econometric analysis of cross section and panel data. Cambridge: The MIT Press. 